\title{
ENTREVISTA COM O PROF. MOACYR DE GOES
}

\section{Dados Biográficos}

Moacyr de Góss por três vezes assumiu Secretarias de Educação: Natal (1960-64), Rio de Janeiro (1987-88) e novamente Natal (1989).

Da primeira vez, na administraçāo do Prefeito Djalma Maranhão, implantou a política de erradicação do analfabetismo, aliando a escola pública ao movimento de educação e cultura popular De Pé no Chão Também se Aprende a Ler.

Após a prisão de 1964, impossibilitado de viver em Natal, reconstruiu a sua vida profissional no Rio de Janeiro. Anistiado, como Professor e Superintendente de Desenvolvimento, ajudou a criar a Extensão Universitária da UFRJ (1986-87).

Divide com Luiz Antônio Cunha a autoria do Livro $O$ Golpe na Educação (6 $6^{\circledR}$ edição, J. Zahar, Rio de Janeiro).

Resistiu à Ditadura participando dos Movimentos do magistério, coordenados pela Confederação dos Professores do Brasil e integrando-se à luta de organização de partidos democráticos.

$P$ - O que foi, em poucas palavras, o movimento DE PÉ NO CHÄO TAMBÉM SE APRENDE A LER?

M - Foi um Movimento de Educação Popular que, tendo nascido no âmbito dos Comitês Nacionalistas, quando das eleições de 1960 para Prefeitos de Natal (RN), veio a se desenvolver na Secretaria Municipal de Educação durante a administração Djalma Maranhão. A sua principal especificidade é justamente esta: um movimento popular que opera dentro de um aparelho de Estado. Daí a fase de 1960-64 ter significado um fortalecimento da Escola Pública Municipal em Natal. Inicialmente programado para ser uma campanha de erradicação do analfabetismo, DE PÉ NO CHÃO extrapolou de sua proposta inicial e se 
converteu numa política de cultura e educação popular na qual a sociedade organizada é o seu principal sujeito e os administradores da Secretaria Municipal de Educação são os seus "intelectuais orgânicos", nas tarefas de planejamento, acompanhamento e avaliaçāo dessa mesma política.

\section{P - Qual a clientela atendida?}

M - Crianças, jovens e adultos. Implantada, principalmente, na periferia da Cidade, onde não existiam escolas, a sua clientela básica foi constituída pelas classes sociais despossuídas. Isso não significou uma exclusão de outras classes sociais, considerando a abrangência da proposta e o envolvimento da sociedade, como um todo.

\section{P - Qual era formação dos professores?}

M - O corpo técnico da Secretaria Municipal de Educação era constituído de profissionais qualificados em Escola Normal e Universidade. Considerando a falta de professores, na época, DE PE NO CHÃO preparou os seus próprios recursos humanos que operaram nas salas de aula. Assim, através dos Cursos de Emergência (quatro meses de duração, cinco horas de aula por dia, inclusive aos sábados) foram qualificados 500 monitores entre 1960-63. Os professores diplomados por Escola Normal foram reciclados para desempenhar as funções de supervisores. Cada Supervisor era responsável pelo desempenho de 20 monitores. Semanalmente, o Supervisor se reunia com os seus monitores e com eles discutia o processo de trabalho verificado "in loco" pelo Supervisor, quando de suas visitas às classes. Quinzenalmente, os Supervisores se reuniam com a Direção da SME, para avaliação do trabalho. Assim, este acompanhamento muito próximo se transformou na chave da qualidade pedagógica.

Ainda para melhor qualificação docente foi criado um Centro de Formação de Professores (responsável pelos Cursos de Emergência e implementação da política educacional, inclusive de expansão para o interior do Rio Grande do Norte), um Ginásio Normal (de quatro anos) e um Colégio Pedagógico (de sete anos).

Para a Campanha DE PÉ NO CHĀO TAMBÉM SE APRENDE UMA PROFISSĀO, os monitores eram recrutados entre profissionais e artesāos que desempenhavam os respectivos ofícios.

\section{$P$ - Quais os principais resultados?}

M - Em três anos, uma matrícula acumulada de cerca de $\mathbf{4 0 . 0 0 0}$ alunos (lembrar que Natal, á época, contava com uma população de 160.000 habitantes). 500 profissionais qualificados para a regência de classes. Índices de aprovação de $60 \%, 74 \%$ e $85 \%$, respectivamente, em 1961, 62 e 63. Custo-aluno médio anual de menos de dois dólares. 
DE PÉ NO CHÃO, numa concepção de Terceiro Mundo, isto é, contando, apenas, com os recursos de uma Prefeitura do Nordeste, respondeu a quatro desafios básicos da escola brasileira:

A- Espaço físico, Respaldado pelo movimento social organizado os Comitês Nacionalistas - a Prefeitura, na impossibilidade de construções de alvenaria, implantou uma rede de Acampamentos Escolares isto é, contruções de grandes galpões de palha de coqueiro. O movimento não confundiu Escola com Prédio Escolar. A Escola funcionou, mesmo sem prédio escolar.

B- Pessoal. Ao qualificar o seu próprio pessoal docente e intermediar o seu trabalho com a cooperação de quadros oriundos da Academia.

C- Material didático. A partir de 1963 a SME produziu o seu próprio material docente, com isso reduzindo a alienação e aproximando a sua política educacional da realidade nordestina.

D- Acompanhamento docente. A rede de intercomunicações permanente Monitor-Diretor de Acampamento-Supervisor-Equipe Técnica do Centro de Formação de Professores assegurou a qualidade pedagógica da política educacional.

\section{$P$ - Como terminou o movimento?}

M - Foi destruído pelo Golpe de Estado de 1964, sob a acusação de que estava comunizando o Nordeste. Igual destino tiveram o Movimento de Cultura Popular do Recife (MCP), o Método Paulo Freire, o Centro Popular de Cultura da UNE (CPC). O Movimento de Educação de Base (MEB) sobreviveu, mas perdeu as características de Movimento de Educação Popular, sua matriz ideológica. médio prazo?

P - Como o Sr. avalia a atual situação do Brasil e que perspectiva vê a

M - Para responder à pergunta teríamos que organizar um Curso, não é? Mas, respondendo, apenas, pelo óbvio. A situação é de uma grave crise. Para ficar só na nossa área, é visível a proposta de sucateamento da educação pública. A educação virou "Marketing" político. Não há seriedade - e, conseqüentemente, credibilidade - para as propostas que estão nos jornais.

A médio prazo espero uma mobilização da sociedade civil, a sua auto-crítica pelo comportamento assumido a partir da Nova República ("Nova", hein ?) e uma retomada da discussão e encaminhamento das grandes questōes nacionais.

P - O que falta para a educação brasileira "dar certo" ?

M - Uma vontade política, realmente, responsável. 
M - Uma vontade política, realmente, responsável.

P - Que saídas o Sr. vê para a Crise educacional brasileira?

M - Aqui seria outro Curso, não é? Mas, vamos ao 6́bvio:

A - Aplicar em educação 5 a $6 \%$ do PIB.

B - Corrigir as distorçōes e impedir a malversação dos dinheiros públicos na aplicação desses recursos.

C - Aplicar os recursos públicos nas redes públicas.

D - Gerenciar corretamente a aplicação dos recursos públicos para cumprimento de um Plano de Educação, democraticamente discutido, definido, em suas linhas gerais no plano nacional e operacionalizado ao nível descentralizado de Estados e Municípios.

E - Acompanhamento e controle social sobre as políticas estatais.

F - Vergonha na cara.

Rio de Janeiro, 08 de Janeiro de 1992. 